\title{
PERLINDUNGAN HUKUM TERHADAP KORBAN TINDAK PIDANA PENGHINAAN CITRA TUBUH (BODY SHAMING)
}

\author{
Ni Made Yeni Sukmawati, Anak Agung Sagung Laksmi Dewi, Ni Made Sukaryati Karma \\ Fakultas Hukum Universitas Warmadewa, Denpasar-Bali, Indonesia \\ yenisukma86@yahoo.co.id, laksmiidewi@gmail.com, sukariati64@gmail.com
}

\begin{abstract}
Abstrak
Body Shaming merupakan istilah yang sedang tren saat ini, dimana mengkritik atau mengomentari fisik seseorang secara negatif atau pun dengan ujaran yang bermaksud mengejek atau menghina fisik maupun penampilan seseorang termasuk ke dalam kategori ini. Perlindungan Hukum terhadap korban body shaming perlu mendapakan perhatian yang sangat serius guna menangani fenomena-fenomena yang marak terjadi saat ini di media social khususnya. Penelitian ini mengkaji pengaturan tindak pidana penghinaan citra tubuh (body shaming) ditinjau dari hukum positif dan menjelaskan perlindungan hukum yang diberikan terhadap korban dalam tindak pidana penghinaan citra tubuh (body shaming). Penelitian ini menggunakan metode penelitian normatif dengan menerapkan pendekatan Perundang-undangan yang mana mengacu pada bahan hukum primer dan bahan hukum sekunder. Pengaturan tindak pidana penghinaan citra tubuh (body shaming) ditinjau dari hukum positif secara umum dapat dilihat dari unsur Penghinaan yang mana diatur dalam Bab XVI KUHP dan dikelompokkan menjadi 6 bagian yakni dari pasal 310 sampai pasal 318 serta selain itu, terdapat pula aturan hukum lain yang mengaturnya secara implisit dalam Pasal 27 ayat (3). Pasal 45 ayat (3) UU ITE. Dengan adanya sanksi berupa sanksi pidana. Bentuk perlindungan hukum yang diberikan terhadap korban dalam tindak pidana penghinaan citra tubuh (body shaming) yaitu dibuatnya kebijakan oleh Negara mengnenai pelarangan dan sanksi tegas bagi para pelanggar seperti sanksi pidana dan denda, melalui lembaga perlindungan saksi dan korban yang didirikan.
\end{abstract}

Kata Kunci : Body Shaming, Perlindungan Hukum, Tindak Pidana

\begin{abstract}
Body Shaming is a term that is currently trending, where criticizing or commenting on someone's physical in a negative way or with speech that intends to mock or insult someone's physical or appearance falls into this category. Legal protection for victims of body shaming needs to get very serious attention in order to deal with the phenomena that are currently happening on social media in particular. This study examines the regulation of the criminal act of insulting body image (body shaming) in terms of positive law and explains the legal protection provided to victims in the crime of insulting body image (body shaming). This study uses a normative research method by applying the legislation approach which refers to primary legal materials and secondary legal materials. The regulation of criminal acts of insulting body image (body shaming) in terms of positive law in general can be seen from the element of humiliation which is regulated in Chapter XVI of the Criminal Code and is grouped into 6 parts, namely from article 310 to article 318 and besides that, there are also other legal rules that regulate it implicitly in Article 27 paragraph (3). Article 45 paragraph (3) of the ITE Law. With sanctions in the form of criminal sanctions. The form of legal protection given to victims in the crime of body shaming is the making of policies by the State regarding prohibitions and strict sanctions for violators such as criminal sanctions and fines, through the established witness and victim protection institution.
\end{abstract}

Keywords: Body Shaming, Legal Protection, Crime

\section{PENDAHULUAN}

Saat ini, mendengar kata kebebasan sebetulnya tidak dapat diartikan benar-benar bebas, yang artinya setiap kebebasan memiliki batasan sehingga tidak melaggar hak serta kewajiban orang lain. Salah satu contohnya dampak buruk dari kebebasan dalam berekspresi yang di dalamnya mencakup kebebasan berbicara yang dalam hal ini mengandung unsur penghinaan dan berdampak negatif bagi orang lain. Penghinaan di Indonesia pada dasarnya termasuk dalam kelompok kejahatan di bidang hukum pidana seperti dalam KUHP da nada juga beberapa Undang-undang lain yang terkait pula yang memuat ketentuan mengenai penghinaan di dalamnya (Achille, 2000). 
Dunia yang bebas seolah tanpa batas hanyalah angan saja. Teknologi informasi dan komunikasi yang berkembang telah mengubah perilaku serta pola hidup masyarakat secara global. Perkembangan tersebut mampu menyebabkan dunia seolah tanpa batas dan sehingga menyebabkan perubahan sosial, budaya, ekonomi dan pola penegakan hukum kearah negatif yang secara signifikan dinamikanya berlangsung demikian cepat. Teknologi informasi saat ini bagaikan pedang bermata dua, karena selain dapat memiliki manfaat sekaligus ancaman bagi manusia sendiri. Sehingga menimbulkan berbagai perbuatan melawan hukum (Widyapramono, 1998).

Maraknya kejadian terkait kasus-kasus mengenai penghinaan bentuk tubuh atau fisik orang lain (body shaming) yang terjadi di masyarakat khususnya dalam interaksi di dunia maya melalui media social, menuntut aturan hukum yang ada sebagai jaminan perlindungan terhadap hak-hak para korban akibat penghinaan citra tubuh (body shaming). Permasalahan terkait mempermalukan bentuk fisik atau tubuh seseorang atau body shaming ini dapat dikatakan sudah tidak tabu atau asing lagi, khususnya di Indonesia (Fitria \& Febrianti, 2020). Body shaming terdiri dari dua suku kata yang masing-masing berarti tubuh dan mempermalukan.

Bentuk bullying baik secara verbal juga termasuk kategori body shaming yang sering terjadi dan kadang tidak disadari keberadaannya. Hal ini disebabkan fenomena ini seperti suatu hal yang biasa terjadi sehingga tidak terlalu dipermasalahkan oleh sebagian orang. Sebab biasanya orang hanya menganggap hal tersebut sebagai candaan atau lelucon biasa. Tanggapan seseorang, terhadap ujarangujaran tersebut berdasarkan makna yang mereka tafsirkan atau berikan terhadapnya. Dalam artian bahwa dalam proses interaksi antar individu bahwa untuk mengetahui sesuatu, menilainya, lalu memberi makna dan memberi tindakan dalam konteks sosial.

Terdapat multitafsir terkait peralatan hukum itu sendiri atau substansinya yang sebenarnya diharapkan dapat menjadi pelindung atau tameng bagi para korban yang mendapatkan perlakuan penghinaan terkait kasus ini, sehingga masih terdapat norma yang dianggap kabur dan tidak jelas makna aslinya, untuk itu bukanlah hal yang tidak mungkin dengan seiring perkembangan zaman serta teknologi informasi maka berbagai macam jejaring sosial akan mengakibatkan dampak-dampak serius terhadap perbuatan-perbuatan body shaming dan bukan hal tidak mungkin semakin meluas dan semakin dianggap biasa.

Ada beberapa penelitian terdahulu yang meneliti terkait masalah ini yaitu Shafa et al., (2020) \& (Rismajayanthi \& Priyanto, 2019) Mengungkapan Tindakan body shaming secara lisan diatur pada Pasal 310 KUHP. Sedangkan secara tertulis dalam bentuk narasi namun ia tidak dapat membuktikannya, maka dia diancam melakukan fitnah dan dapat dikenakan Pasal 311 KUHP. Selanjutnya (Ndruru et al., 2020) Mengungkapkan Pertanggungjawaban pidana pelaku penghinaan citra tubuh (body shaming), dapat dilihat dari beberapa unsur yaitu, adanya perbuatan dan kesalahan yang dilakukan, adanya tindakan melawan hukum, adanya objek dan tujuan yang hendak dicapai. Dari paparan fenomena di atas, penelitian ini mengkaji mengkaji pengaturan tindak pidana penghinaan citra tubuh (body shaming) ditinjau dari hukum positif dan menjelaskan perlindungan hukum yang diberikan terhadap korban dalam tindak pidana penghinaan citra tubuh (body shaming).

\section{METODE PENELITIAN}

Penelitian ini menggunakan penelitian hukum normatif dengan pendekatan Perundang-undangan bersama dengan pendekatan secara konseptual. Adapun sumber bahan hukum yang digunakan adalah bahan hukum primer meliputi Undang-undang Nomor 19 Tahun 2016 tentang Perubahan atas Undang-undang Nomor 11 Tahun 2008 tentang Informasi dan Transaksi Elektronik (UU ITE) serta data sekunder meliputi beberapa jurnal, literature, dan buku ilmiah terkait masalah yang sedang dikaji. Data diperoleh melalui observasi dan dokumentasi, selanjutnay data dianalisis secara kualitatif deskriptif.

\section{HASIL DAN PEMBAHASAN}

\section{Pengaturan Tindak Pidana Penghinaan Citra Tubuh Ditinjau dari Hukum Positif}

Masalah terkait dengan penghinaan bentuk tubuh atau body shaming bukan suatu hal yang tabu atau asing lagi di Indonesia. Bentuk bullying baik secara verbal juga termasuk kategori body shaming yang sering terjadi dan kadang tidak disadari keberadaannya. Hal ini disebabkan fenomena ini seperti suatu hal yang biasa terjadi sehingga tidak terlalu dipermasalahkan oleh sebagian orang. Citra tubuh merupakan suatau gambaran secara mental mengenai tubuhnya dapat berupa pikiran, penilaian, 
perasaan, sensasi, kesdaram serta perbuatan yang berhubungan dengan bentuk tubuh yang dimiliki setiap individu (Mukhlis, 2013). Istilah citra tubuh pada intinya adalah gambaran yang dimiliki seseorang untuk menyesuaikan dengan bagaimana orang lain memperhatikan dirinya, sehingga berkeinginan melihat bagaimana respon orang lain terhadap dirinya ketika memperhatikannya. Citra tubuh merupakan persepsi dirinya yang dilihat dari sudut pandang mata orang lain, jadi mudah terpengaruh dengan penilaian orang lain di sekitarnya.

Istilah tindak pidana penghinaan dapat dikatakan pula sebagai tindak pidana terhadap kehormatan. Maksud serta tujuan dari Pasal tersebut yakni melindungi kehormatan, maka tindak pidana terhadap kehormatan, lebih tepat dan hal ini dilihat dari segi sasaran atau objek delik. Tindak pidana kehormatan atau penghinaan merupakan tindak pidana yang dapat merusak kehormatan dan nama baik seseorang dengan menyerang hak orang lain. Seperti ketika dalam media sosial yang sangat banyak jenisnya saat ini, seseorang melihat foto orang lain dan dengan tanpa berpikir akan resikonya, mereka dengan bebas berkomentar mengenai fisik orang tersebut, yang tak jarang mengandung unsur negative seperti penghinaan, pengejekan atau bullyin (Leden, 2002).

Pengaturan yang dapat dijadikan sebagai dasar untuk merujuk pada tindak pidana terhadap perbuatan body shaming ini dapat dilihat dalam Pasal 310, Pasal 311 dan Pasal 315 KUHP. Pengertian makna penghinaan sendiri juga pada umunya dikaitkan dengan tindak pidana terhadap kehormatan seseorang. Untuk tindak pidana kategori penghinaan ringan diatur dalam Pasal 315 KUHP bias juga dikatakan sebagai tindak pidana penghinaan biasa. Namun sayang, pasal tersebut dikatakan belum dapat mengakomodir seluruh perilaku atau tindakan terkait penghinaan terhadap citra/bentuk tubuh seseorang denagn mana juga belakangan ini sering terjadi. Pasal 315 KUHP masih terbatas terhadap pengaturan atas sengaja atau tidaknya penghinaan itu dilakukan seseorang sehingga dapat dikategorikan bersifat pence, aran atau tidak, baik bentuknya berupa perbuatan di muka umum oleh seseorang atau langsung kepada orang itu sendiri menggunakan lisan maupun tulisan. Pada ketentuan Pasal 315 KUHP ini tidak dijelaskan dengan terang dan rinci mengenai penghinaan seperti apa dan dalam bentuk apa saja yang dapat dikatakan penghinaan ringan, atau dengan kata lain rumusan dalam KUHP ini kita hanya dapat menjumpai pengaturan penghinaan dalam arti yang luas dan kurang terperinci sehingga tak jarang multitafsir terjadi dalam penindakannya. Selain Pasal 315 KUHP yang merupakan salah satu paying hukum dalam melakukan dasar untuk menjatuhi pidana terkait perbuatan penghinaan terhadap citra tubuh (body shaming), disamping itu juga terdapat terdapat ketentuan terkait disamping KUHP yang juga memberikan pengaturan mengenai hal serupa yang sifatnya mengkhusus lagi dan sudah digunakan dalam putusan pengadilan yaitu dapat dijumpai dalam Undang-Undang Nomor 11 Tahun 2008 tentang Informasi dan Transaksi Elektronik yang telah dirubah menjadi Undang-undang Nomor 19 Tahun 2016 (UU ITE). Pasal 27 ayat (3) UU ITE mengenai tindak pidana penghinaan terhadap citra tubuh (body shaming), dapat dijadikan rujukan terhadap delik penghinaan ini selain daripada di dalam KUHP itu sendiri. Berdasarkan hal tersebut secara eksplisit sebenarnya tidak terdapat kalimat yang menyebut tindak pidana penghinaan citra tubuh atau body shaming, yang ada hanya klausul berupa "penghinaan atau pencemaran nama baik" yang sifatnya lebih umum dan sering kali menimbulkan multitafsir juga.

\section{Bentuk Perlindungan Hukum yang Diberikan Terhadap Korban dalam Tindak Pidana Citra Tubuh (Body Shaming)}

Body shaming atau mengomentari kekurangan dari fisik orang lain dapat termasuk perbuatan merundung secara verbal terhadap kondisi fisik tubuh seseorang. Secara sederhana, perbuatan body shaming merupakan perilaku menyimpang dan negatif. Istilah ini berarti mencela keadaan bentuk tubuh orang lain dan mengakibatkan pengaruh buruk bagi para korbannya karena membuat rasa percaya diri korban menjadi hilang. Dimana media khususnya di dunia maya yaitu media sosial berperan besar dalam pelaksanaan perbuatan ini. Body shaming sering dilakukan tanpa disadari oleh pelaku. Bahkan dalam komunikasiatau interaksi sehari-hari pun tak jarang terselip kalimat candaan yang mana termasuk ke dalam kategori body shaming.

Seperti ketika dalam media sosial yang sangat banyak jenisnya saat ini, seseorang melihat foto orang lain dan dengan tanpa berpikir akan resikonya, mereka dengan bebas berkomentar mengenai fisik orang tersebut, yang tak jarang mengandung unsur negative seperti penghinaan, pengejekan atau bullying. Perbuatan menyimpang ini dapat menjadikan seseorang semakin down, merasa kurang percaya diri, merasa tidak aman serta tidak puas terhadap fisik atau penampilan fisik yang dimiliki 
dan mulai kehilangan keterbukaannya, bahkan tak jarang fenomena ini berujung tragis seperti bunuh diri. Perlindungan hukum merupakan bentuk upaya untuk memberikan pemenuhan hak guna membantu korban yang membutuhkan seperti memberikan perasaan aman, tenang dan nyaman kepada korban maupun saksi, sebagai bagian dari perlindungan pada masyarakat itulah tujuan dari perlindungan hukum. Hal ini merupakan bentuk yang dapat diwujudkan melaui kompensasi, bantuan hukum, restitusi hingga pelayanan medis seperti psikolog atau psikiater (Srilampau, 2009).

Pengaturan mengenai informasi transaksi dan elektronik di Indonesia dapat dilihat dalam UU ITE. Peraturan ini diharapkan mampu untuk memberikan kepastian hukum bagi masyarakat serta bangsa Indonesia, mengenai segala bentuk transaksi yang dapat terjadi dan dilakukan di dunia siber. Untuk itu dalam Pasal 5 dan 6 UU ITE sudah diatur mengenai pengakuan bahwa alat bukti hukum yang sah dapat berupa informasi dokumen elektronik, selain itu terdapat pula tanda tangan elektronik pada Pasal 11 dan 12, penyelenggaraan sertifikat elektronik Pasal 13, 14 dan penyelenggaraan sistem elektronik pada Pasal 15 dan 16.

Menurut Rahmawati, (2019) Ada beberapa bentuk perlindungan yang menjadi hak korban penghinaan citra tubuh (body shaming) melalui sosial media, antara lain:

1. Dibuatnya kebijakan oleh Negara mengnenai pelarangan dan sanksi tegas bagi para pelanggar seperti sanksi pidana dan denda.

2. Melalui lembaga perlindungan saksi dan korban yang didirikan;

3. disediakannya aparat yang nantinya akan memberikan perlindungan secara khusus, seperti penyidik khusus siber;

4. dinyatakannya bahwa tindak pidana penghinaan atau pencemaran naa baik cenderung menimbulkan kerugian immaterial dibandingkan materiil sehingga sanksi pidana serta denda dianggap relevan, karena kerugian tidak dapat dinilai dengan uang.

5. Melakukan penutupan akun yang muatannya negatif dan tidak baik sehingga berdampak buruk dan tidak bermanfaat, yang dilakukan melalui Sistem jaringan elektronik oleh pihak berwenang seperti Kominfo misalnya

Penghinaan citra tubuh (body shaming) termasuk ke dalam delik aduan. Jadi hal tersebut baru dapat dilakukan langkah hukum serta dilakukan proses jika telah terdapat adanya aduan dari korban yang merasa menjadi sasaran kejahatan ini. Delik aduan adalah delik yang hanya akan dapat diproses ketika sudah ada pengaduan dari korban terkait suatu tindak pidana yang terjadi dan merasa dirugikan untuk itu. Maka karena hal tersebut, polisi baru dapat melakukan tindak lanjut terhadap kasus setelah adanya pengaduan, itu berbeda dari delik pada umumnya, juga pada delik aduan, korban memiliki kewenangan untuk melakukan pencabutan laporan tersebut, apalagi jika permasalahan berhasil atau dapat diselesaikan secara mediasi misalnya tanpa menempuh jalur hukum (Mansur \& Gultom, 2005).

Jika penghinaan berupa hinaan, ejekan terhadap fisik seperti, wajah, bentuk atau postur tubuh, warna kulit seseorang melalui sosial media atau perantara elektronik dapat masuk ke dalam kategori sebagaimana Pasal 27 Ayat (3) jo Pasal 45 Ayat (3) UU ITE. Pasal 27 ayat (3) menyebutkan bahwa siapapun mentransmisikan, mendistribusikan dan/atau membuat secara sengaja tanpa hak suatu hal yang dapat diakses melalui Informasi dan/atau dokumen elektronik, dimana di dalamnya terdapat unsur atau muatan menghina dan/atau mencemarkan nama baik, merupakan perbuatan yang termasuk kategori psal ini. Sedangkan Pasal 45 ayat (3) yang menyebutkan sanksi pidana bagi pelanggar pasal 27 ayat (3) yaitu dengan ancaman denda paling banyak Rp750.000.000,00 (tujuh ratus lima puluh juta rupiah) dan/atau pidana penjara paling lama 4 (empat) tahun, ini lebih masuk akal ketimbang sanksi dalam KUHP saat ini pada pasal 315 tersebut.

Ketika penghinaan bentuk tubuh ini dilakukan langsung secara verbal kepada orang yang dituju, maka mengacu pada pasal 310 KUHP dapat diancaman pidana selama 9 bulan. Lain halnya jika dilakukan secara tertulis seperti dalam bentuk narasi, melalui media sosial, dapat diancam pidana sebagaimana pasal 311 KUHP dengan hukuman penjara selama 4 tahun. Akan tetapi saat ini yang paling relevan dijadikan dasar menjatuhi putusan bagi tindak pidana penghinaan citra tubuh (body shaming) adalah Pasal 315 KUHP. Pasal ini menyatakan bahwa ancaman pidana penjara dan denga yang asing-masih paling lama 4 bulan 2 minggu atau denda sebanyak empat ribu lima ratus rupiah diberikan bagi tiap penghinaan yang dilakukan secara sengaja yang mana tidak bersifat pencemaran maupun dalam bentuk tertulis, baik di hadapan umum atau di hadapan orang bersangkutan langsung, secara lisan ataupun tulisan dan perbuatan, atau bias juga dengan pengiriman surat kepada korban, dianggap sebagai penghinaan ringan atau biasa. 


\section{SIMPULAN DAN SARAN}

\section{Simpulan}

Berdasarkan hasil analisis data, dapat disimpulkan bahwa pengaturan tindak pidana penghinaan citra tubuh (body shaming) ditinjau dari hukum positif dapat dilihat pengaturannya dalam Bab XVI KUHP yang dikelompokkan menjadi 6 bagian yakni khususnya pada pasal 310,311 dan 315 KUHP. Khusus untuk pengguna dunia maya seperti social media contohnya Teknologi informasi saat ini bagaikan pedang bermata dua, karena selain dapat memiliki manfaat sekaligus ancaman bagi manusia sendiri. Sehingga menimbulkan berbagai perbuatan melawan hukum, sehingga ancaman pidananya juga tidak main-main, sebagimana yang dirumuskan Undang-undang Nomor 11 Tahun 2008 tentang Informasi dan Transaksi Elektronik yang telah dirubah menjadi Undang-bndang Nomor 19 Tahun 2016 pada pasal 27 ayat (3) jo Pasal 45 ayat (3). Selanjutnua bentuk perlindungan hukum yang diberikan terhadap korban dalam tindak pidana penghinaan citra tubuh (body shaming) yaitu dibuatnya kebijakan oleh Negara mengnenai pelarangan dan sanksi tegas bagi para pelanggar seperti sanksi pidana dan denda, lalu juga melalui lembaga perlindungan saksi dan korban yang didirikan; disediakannya aparat yang nantinya akan memberikan perlindungan secara khusus, seperti penyidik khusus siber; dinyatakannya bahwa tindak pidana penghinaan atau pencemaran naa baik cenderung menimbulkan kerugian immaterial dibandingkan materiil sehingga sanksi pidana serta denda dianggap relevan, karena kerugian tidak dapat dinilai dengan uang; dan dapat melakukan penutupan akun yang muatannya negatif dan tidak baik sehingga berdampak buruk dan tidak bermanfaat, yang dilakukan melalui Sistem jaringan elektronik oleh pihak berwenang seperti Kominfo.

\section{Saran}

Ada beberapa saran yang diberikan yaitu Secara moralitas, diharapkan bahwa upaya hukumnya dapat memberikan efek jera, sehingga setiap orang dapat menghargai orang lain, setiap individu lain, setiap kelompok, dalam kehidupan sosialnya. Perlu dilakukan kajian ilmiah lebih lanjut tentang aturan hukum terkait penghinaan citra tubuh (body shaming) kepada masyarakat, mengingat banyaknya atuan yang multitafsir dan masih kurang jelas isinya, agar nantinya tidak menjadi suatu kebiasaan yang tidak seharusnya terjadi. Sehingga dapat dijadikan bekal para subyek hukum dalam bertindak dan berperilaku. Bagi para korban diharapkan memberanikan diri untuk mengadukan perbuatan dari pelaku kepada pihak yang berwajib, jadi harus berani untuk yang terbaik. Untuk itu peran orang terdekat dan masyarakat juga sangat penting. Karena resikonya saat ini dapat berdampak besar khususnya bagi mental atau keadaan psikis seseorang atau korban dalam hal ini.

\section{DAFTAR PUSTAKA}

Achille, N. (2000). Etika Hukum Beserta Sanksi Elektronik. Jakarta. Sinar Grafika.

Fitria, K., \& Febrianti, Y. (2020). Pemakaian dan Sikap Perilaku Body Shaming di Media Sosial (Sebuah Studi Etnografi Digital di instagram). Jurnal Media Dan Komunikasi, 3(1), 12-25.

Leden, M. (2002). Tindak Pidana terhadap nyawa dan tubuh. Sinar Grafika.

Mansur, A., \& Gultom, E. (2005). Cyber Law-Aspek Hukum Teknologi Informasi. Bandung. Refika Aditama.

Mukhlis, A. (2013). Berpikir Positif pada Etidakpuasan Terhadap Citra Tubuh (Body Image Dissatisfaction)", Jurnal. Jurnal Psikoislamika, 10(1), 1-14.

Ndruru, M. K., Ismail, \& Suriani. (2020). Pengaturan Hukum tentang Tindakan Penghinaan Citra Tubuh (Body Shaming). Jurnal Tectum, 1(2), 288-295.

Rahmawati, M. (2019). Perlidungan Hukum Terhadap Korban Tindak Pidana Pencemaran Nama Baik Melalui Media Sosial. Jurnal Ilmiah Ilmu Hukum, 1(2).

Rismajayanthi, N. G. A. A. P., \& Priyanto, I. M. D. (2019). Tinjauan Yuridis Terhadap Tindak Pidana Penghinaan Citra Tubuh (Body Shaming) Menurut Hukum Pidana Indonesia. Jurnal Ilmi Hukum, 9(1-15).

Shafa, S. D., Juita, S. R., \& Aryaputra, M. I. (2020). Kebijakan Formulasi Hukum Pidana tentang Penghinaan Citra Tubuh (Body Shaming). Jurnal Law Review, 1(1), 104-113.

Srilampau, S. (2009). Fenomena dan Perlindungan Hukum di Indonesia. Jakarta. Sinar Grafika. Widyapramono. (1998). Kejahatan di bidang Komputer. Jakarta. Pustaka Sinar Harapan. 